\title{
İnsan Hastalıklarında Epigenetiğin Rolüne Klinik Bakış
}

\author{
Emre ÖZGÜR ${ }^{*}$, Hülya TIĞLI** ${ }^{*}$, Hatice TIĞLI ${ }^{* * *}$
}

$\ddot{O} \mathbf{z}$

Son yıllarda sayısı giderek artan çalışmalar, epigenetik değişikliklerin hastalık süreci üzerinde önemli etkilerinin olduğunu ortaya koymaktadır. Bu süreçte teknolojik gelişmelerin de büyük katkıları ile epigenetik bilgi genetiğin ötesine taşınmıştır. Epigenetik konusunda elde edilen yeni bulgular sadece hastalıklarla ilişkili faktörleri daha iyi anlamamızı sağlamakla kalmaz, aynı zamanda terapötik girişim için yeni kapılar da açmaktadır. Bu derlemede, epigenetik kavramı ve insan hastalıklarında epigenetiğin önemi irdelenmiştir.

Anahtar Kelimeler: Epigenetik, genetik, kanser, insan hastalıkları.

\section{Clinical Overview of the Role of Epigenetics in Human Diseases}

\begin{abstract}
In recent years, a growing number of studies have shown that epigenetic changes have significant effects on the disease process. In this process, epigenetic knowledge has gone beyond genetics with the great contributions of technological developments. New findings in epigenetics not only enable us to better understand the disease-related factors but also open new doors for therapeutic intervention. In this review, the concept of epigenetics and the importance of epigenetics in human diseases are examined.
\end{abstract}

Keywords: Epigenetics, genetics, cancer, human diseases.

\footnotetext{
Derleme Makale (Review Article)

Geliş / Received: 06.01.2020 \& Kabul / Accepted: 30.01 .2020

${ }^{*}$ Arş. Gör. Dr., İstanbul Üniversitesi, Onkoloji Enstitüsü, Temel Onkoloji Anabilim Dalı, Çapa, İstanbul, Türkiye, E-posta: emre.ozgur.86@istanbul.edu.tr, ORCID ID https://orcid.org/oooo0002-4995-4759.

** Dr. Öğr. Üyesi, İstanbul Gelişim Üniversitesi, Sağllk Bilimleri Yüksekokulu, İstanbul, Türkiye, E-posta: hulyatigli@yahoo.com, ORCID ID https://orcid.org/oooo-0001-5997-0122

*** Dr. Öğr. Üyesi, İstanbul Gelişim Üniversitesi, Sağlık Bilimleri Yüksekokulu, İstanbul, Türkiye, E-posta: haticetigli@yahoo.com, ORCID ID https://orcid.org/oooo-0001-9713-4926
} 


\section{Giriș}

Genetik ve epigenetik değişiklikler, uzun zamandır önemli bilgilerin depolanması ve genetik bilginin düzenlenmesi için ön koşul olan iki ayrı mekanizma olarak düşünülmüştür. Sonuçta her ikisi de anormal gen ekspresyonu ile sonuçlanmakta ve farklı hastalık fenotiplerine yol açmaktadırlar. Epigenetik mekanizmalarda gerçekleşen değişiklikler genetik mutasyonlara; epigenetik düzenleyicilerdeki genetik mutasyonlar da değişmiş bir epigenomun ortaya çıkmasına yol açabildiğinden, genetik ve epigenetik mekanizmalar iç içe geçmiş halkalar olarak görülebilir.

“Epigenetik" kavramının 1940'larda Waddington tarafından ilk olarak dile getirilmesinden bu yana, epigenetik düzenlemede yer alan mekanizmaların aydınlatılması konusunda bir hayli yol alınmıştır ${ }^{1}$. DNA ve histon proteinlerinin kovalent modifikasyonları, kromatinin organizasyonu ve işlevinin düzenlenmesinde rol oynayan iki anahtar epigenetik modifikasyon olarak karşımıza çıkmaktadır. İlginç bir şekilde, bu iki modifikasyon farklı enzim grupları ve farklı kimyasal reaksiyonlarla gerçekleştirilir. Diğer taraftan, gen baskılamasının düzenlenmesinde bu iki sistem arasında biyolojik bir etkileşim olduğu görülmektedir.

$\mathrm{Bu}$ derlemede, epigenetik yolakları düzenleyen bileşenlerde meydana gelen değişikliklerin neden olduğu insan hastalıkları ve bunların klinik sonuçları kısaca anlatılmaktadır. Ayrıca gelecekte tanıda kullanılabilecek kan temelli epigenetik biyobelirteçlerin potansiyeli kısaca ele alınmaktadır.

\section{DNA Metilasyonu ve Hastalıkla İlişkisi}

İnsan genomunda DNA metilasyonu, sadece genom boyunca rastgele dağılmış olan ve sıklıkla genlerin $\mathrm{CpG}$ adacıkları olarak promotör bölgelerinde kümelenen $\mathrm{CpG}$ dinükleotitlerinde meydana gelir (Şekil 1). 


\section{Şekil 1. Fizyolojik durum ile kanser ve yaşlanma süreçlerinde DNA metilasyon modelleri}
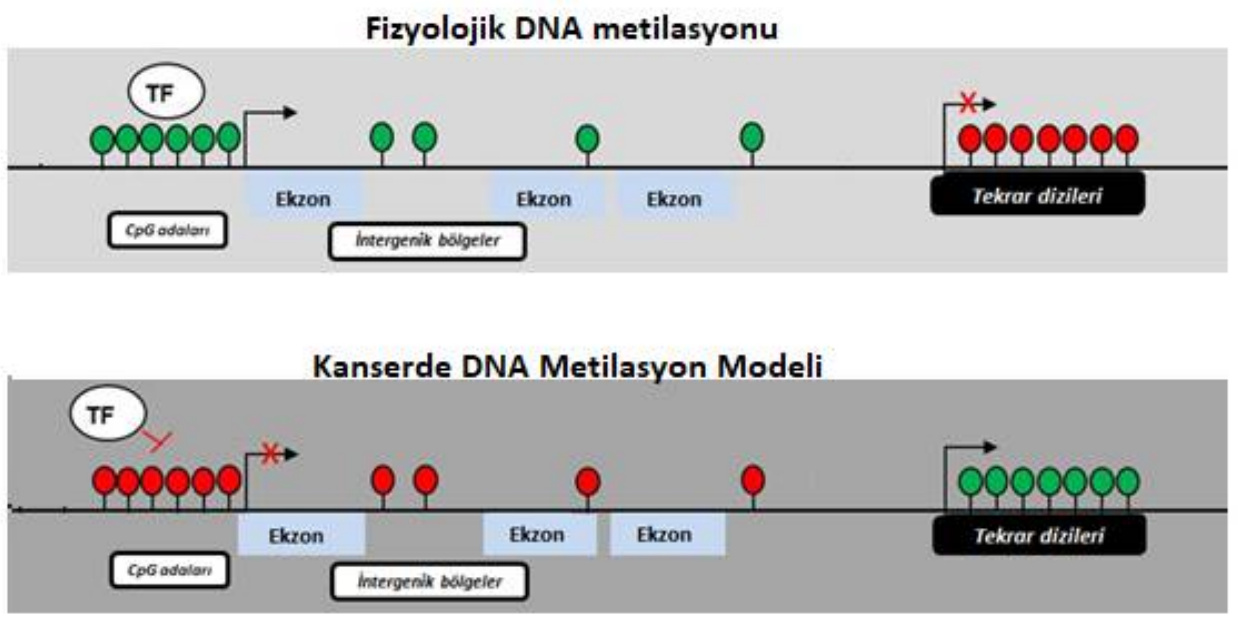

Yaşlanmada DNA Metilasyon Modeli

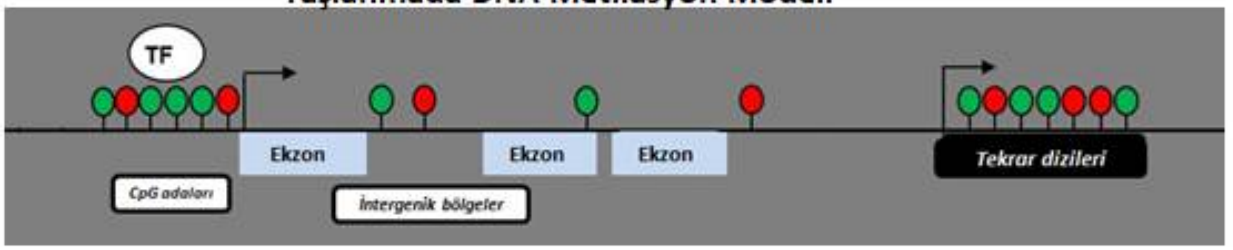

Üstteki görsel, CpG'lerin transkripsiyona uğradığı (yeşil) transkripsiyonel aktiviteye izin veren sağlıklı durumu gösterirken, tekrarlayan bölgeler yoğun metillenmiş (kırmızı) halde tutulur. Bu tablo, kanserde tersine döner; metillenmemiş (yeşil) tekrarlayan bölgelerde metilasyon kaybı ile birlikte promotörlerdeki CpG adacıkları yoğun şekilde metillenir (kırmızı). Tekrarlayan dizilerdeki bu metilasyon kaybı, bu bölgelerin aktifleşmesine ve genom kararsızlığına yol açar. Yaşlanma sürecinde ise epigenetik bilgi, dış ve endojen faktörlere cevap olarak sporadik olarak değişir. Bu durum kanser, nörodejeneratif hastalıklar, ateroskleroz ve iltihaplanma gibi yaşa bağlı hastalıkların özellikleri olan anormal DNA metilasyon ve gen ekspresyonunun değişimine yol açar (TF, transkripsiyon faktörü).

CpG dinükleotidinin sitozin bazı, metil grubu ile kovalent modifikasyona yatkınlı gösterir. DNA metilasyonu, fizyolojik olarak gen susturma, transpozonlar veya endojen retrovirüslerin sessizleştirilmesi, genomik imprinting, yaşlanma ve X-inaktivasyonu 
gibi çeşitli biyolojik işlevlere katılır. Kalıtılabilen ve stabil bir baskıcılayıcı epigenetik işaret olarak DNA metilasyonu, DNA metiltransferaz (DNMT) enzimi ailesi tarafından katalizlenir. DNA metiltransferaz 1'deki mutasyonlar demans ve işitme kaybı içeren kalıtsal duyusal otonomik nöropati ve narkolepsi gibi nörodejeneratif hastalıklar ilişkili

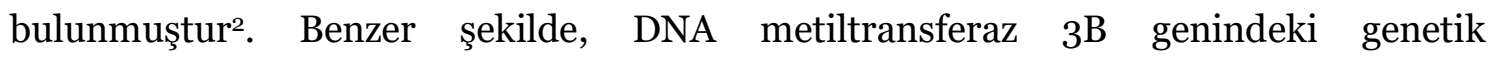
mutasyonların, Yüz Anomalileri Sendromu (ICF) vakalarının çoğunluğundan sorumlu oldukları bildirilmiştir3. Son yıllardaki kanser genom dizileme çalışmaları, akut miyeloid lösemili hastaların \%25'inde DNA metiltransferaz 3A'da tekrarlayan mutasyonlar tanımlamıştır4,5. DNMT'larda, hastalık fenotipi ile ilişkili olduğu gösterilen çok sayıda DNA polimorfizmi tanımlanmıştır. Sistematik bir araştırmada, El-Maarri ve ark. beş DNMT geninin tüm kodlayan bölgelerinde bu polimorfizmlerin bulunduğunu gösterirken, nadir bir DNA metiltransferaz 3L varyantı (R271Q, rs113593938) ile subtelomerik bölge hipometilasyon arasında önemli bir bağlantı olduğunu gösterdiler 6 . Bununla birlikte, DNA metilasyonu sadece DNMT'ların işlevine tabii değildir. DNA demetilaz enzimleri, DNA metilasyon reaksiyonunu tersine çevirerek metil grubunu DNA'dan uzaklaştırırlar. DNA demetilazlardaki genetik anomaliler de hastalığa yol açabilmektedir. Örneğin, Ten-Eleven translokasyon (TET) proteini, DNA demetilaz olarak işlev görür. TET2 genindeki mutasyonlar, miyelodisplastik sendrom, miyeloproliferatif neoplazm, AML ve kronik miyelomonositik lösemide bildirilmiştir7-9. DNA metilasyonun oluşmasında görev alan proteinlerden, metil-bağlayan proteini (MBD) kodlayan dizilerdeki mutasyonların, karmaşı insan hastalığı fenotiplerine yol açtı̆̆ı ortaya çıkmaktadır. Örneğin, metil-CpG bağlayan protein 2'deki (MECP2) mutasyonların, çoğunlukla kadınları etkileyen nörodejeneratif bir hastalık olan Rett sendromuna neden olduğu bilinmektedir ${ }^{10}$.

DNA metilasyonu ile ilişkili genlerdeki mutasyonların yanı sıra, bu genlerin anormal düzenlemesi de insan sağlığı üzerinde önemi etkilere sahiptir. Genomik imprinting çalışmaları, damgalanmış genomik lokuslardaki metilasyon kaybının, imprinting kaybına (LOI) yani önceden susturulmuş genin anormal derecede yüksek ifadesine neden olabileceğini göstermiştir. Bu durum ciddi genetik hastalık formlarına yol açabilmektedir. Bu tür anormal aktivasyonun tipik bir örneği, Wilms tümöründe insülin benzeri büyüme faktörü 2 (IGF2) lokusundaki LOI'dir ${ }^{11,12}$. Daha sonraki ylllarda bu değişikliğin farklı insan malignitelerinde de gerçekleştiği gösterilmiştir. Bugüne 
kadar, X kromozomu üzerinde herhangi bir imprinting bölgesi saptanmazken, DNA metilasyonu, X kromozomunun sessizleştirilmesi sürecinde önemli bir rol oynar. Ayrıca, Turner sendromu (45, XO) üzerine yapılan bir çalışma, iki X kromozomundan birinin tamamıla eksik olmasının, otozomal kromozomlar üzerindeki DNA metilasyon seviyelerini etkilelediğini göstermiştir ${ }^{13}$.

Kanserlerde, DNA hipometilasyonu onkogenleri aktive ederek kromozom kararsızlı̆̆ını başlatırken, DNA hipermetilasyonu tümör baskılayıcı genlerin susturulmasına yol açar. DNA hipermetilasyonunun gözlendiği CpG adacıklarını yoğun şekilde içeren kanser dokuları, 'CpG adası metilatör fenotip,' (CIMP) olarak adlandırılmıştır ve son on yılda mesane, meme, endometriyal, gastrik, glioblastom, hepatosellüler, akciğer, yumurtalık, pankreas, prostat, renal hücre kanserleri, lösemi, melanom, duodenal adenokarinom, adrenokortikal karsinom ve nöroblastom gibi çeşitli tümör tiplerinde tanımlanmıştır ${ }^{14-}$ 17. Gen spesifik metilasyon değişiklikleri dışında, genomun tekrarlayan elementlerinde (ör. LINE-1) metilasyon düzeyleri kanserogenez sürecinde azalır (hipometilasyon). LINE-1 elementindeki metilasyon değişikleri çeşitli kanser tipleri (kolon, testis, kolon, mesane, mide, baş-boyun ve nöroendorkin tümörler) ile sistemik lupus eritematozus ve nöral tüp defektlerinin gelişimi ile ilişkilendirilmiştir. Tekrar elementlerindeki metilasyon durumu, genellikle global DNA metilasyon seviyelerini tahmin etmek için belirteç olarak kullanılır ${ }^{18}$.

DNA metilasyon kalıp ya da düzeyleri artan yaş ile birlikte değişmektedir. Yaşa bağlı olarak, belli genomik bölgelerdeki metilasyonun arttığı ya da azalabildiği gösterilmiştir. Alzheimer, Parkinson gibi yaşa bağlı nörodejeneratif hastalıkların gelişiminde, DNA metilasyonunun önemli bir rolü olduğu belirlenmiştir ${ }^{19,20}$. Benzer şekilde, majör depresif bozukluk gibi nöropsikiyatrik hastalıklarda, beynin farklı anatomik bölgelerinde (prefrontal korteks ve hipokampus gibi) hipermetilasyona uğrayan genler tanımlanmıştır ${ }^{21}$. Tüm bunlara ilaveten, genom düzeyinde metilasyon verilerinin artması, araştırmacılara, güvenilir bir şekilde yaş tahmini az sayıdaki bazı CpG bölgelerinin yeterli olabileceği yönünde bulgular sağlamıştır ${ }^{22,23}$.

\section{Histon Modifikasyonları ve Hastalıkla İlişkisi}

Gen düzenlenmesinde sadece DNA metilasyonu yer almaz. Genom organizasyonu ve dinamikleri için başka biyolojik süreçler de gereklidir. Bu süreçlerde histon proteinleri 
çok önemli görevler üstlenirler. Histonların N-terminal kuyruklarında gerçekleşen modifikasyonlar, gen transkripsiyonu, kromatin organizasyonu, DNA onarımı ve DNA replikasyonu gibi önemli biyolojik süreçlere katılan ikinci anahtar epigenetik mekanizma olarak karşımıza çıkarlar (Şekil 2).

\section{Şekil 2. Nükleozom ve histon modifikasyonları}

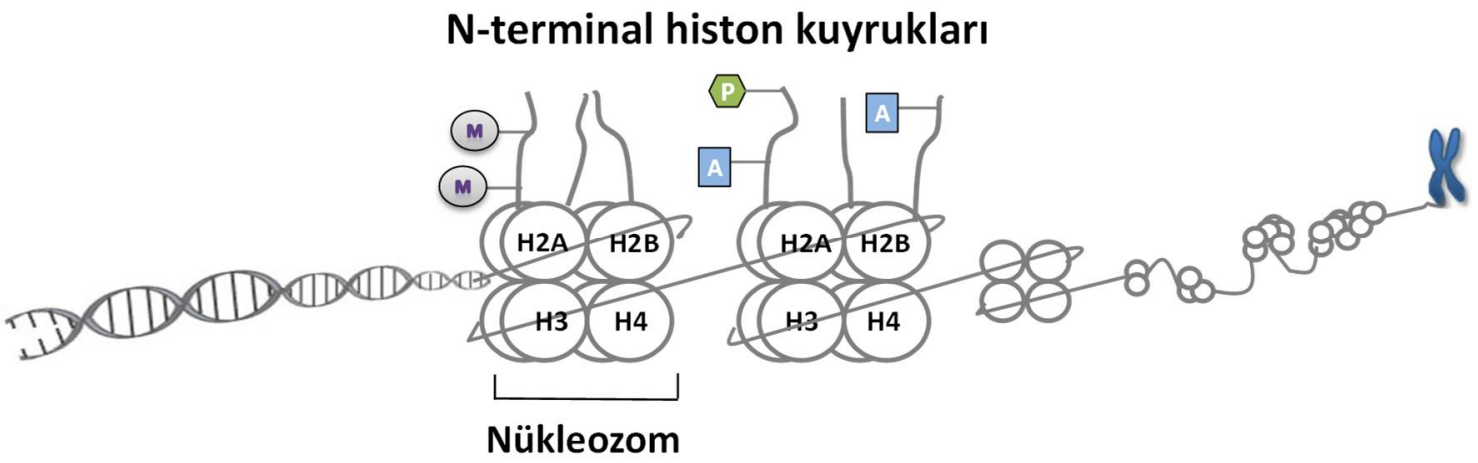

Şekilde, genomun erişilebilirliğini ve fonksiyonunu düzenlemek için çok önemli olan nükleozomları oluşturmak için histon proteinlerinin etrafına sarılmış DNA gösterilmektedir. Çok kararlı bir protein-DNA kompleksi olan nükleozom, transkripsiyon faktörü bağlanmasını inhibe etmek veya kolaylaştırmak için yapısal düzenlemelere (gevşetme veya sıkılaştırma) uğrar. Histon kuyruklarında, gen transkripsiyonunun aktivasyonuna veya baskılanmasına yol açan modifikasyonlar gösterilmiştir. ( $\mathrm{M}=$ Metilasyon, $\mathrm{A}=$ Asetilasyon, $\mathrm{P}=$ Fosforilasyon)

Bugüne kadar, histon modifikasyonlarının dokuz farklı tipi tanımlanmıştır: asetilasyon, metilasyon, fosforilasyon, ubikutinasyon, sumolasyon, ADP-ribozilasyon, deiminasyon, prolin izomerizmi, propiyonilasyon. Bunlardan en yaygın olarak çalışılan modifikasyonlar asetilasyon (ac) ve metilasyondur (me).

Histon lizin asetilasyonu, gen ekspresyonu ile pozitif korelasyon gösterir ve histon lizin asetiltransferaz enzimlerinin (HAT'lar) tarafindan katalizlenir. Histon lizin deasetilazların (HDAC) (KDAC) ise histonlardan asetil grubunu uzaklaştıran enzimlerdir. Öte yandan, histon metilasyonu temel olarak histon kuyruklarındaki lizin (K) veya arginin $(\mathrm{R})$ rezidülerinde meydana gelir ve transkripsiyonel aktivasyon veya baskılanma ile ilişkilidir: $\mathrm{H}_{3} \mathrm{~K}_{4}, \mathrm{H}_{3} \mathrm{~K}_{3} 6$ ve $\mathrm{H}_{3} \mathrm{~K}_{79}$ 'un metilasyonu gen aktivasyonuna yol açarken, $\mathrm{H}_{3} \mathrm{~K} 9$ ve $\mathrm{H}_{3} \mathrm{~K}_{2} 7$ veya $\mathrm{H}_{4} \mathrm{~K} 20$ 'nin metilasyonu gen susturulması ile 
ilişkilidir. Arginin metilasyonu, protein arginin metiltransferazlar (PRMT'lar) ailesi tarafından katalize edilirken, lizin metilasyonu ise sırasıyla histon lizin metiltransferazlar (HMT'lar) ile oluşturulur ve histon demetilazlar (HDM'lar) tarafından uzaklaştırılır. Akut miyeloid lösemi, tükürük karsinomu ve mesane kanserinde yüksek $\mathrm{H}_{3}$ K9me3 düzeyleri rapor edilmiştir ${ }^{24-26}$. Benzer şekilde, H4K2Ome3'ün küçük hücreli dışı akciğer kanserinde tümör ilerlemesi ve prognozu ile korele olduğu gösterilmiştir ${ }^{27}$. Özellikle H3K27 rezidülerini hedef alan en iyi çalışılmış HMT enzimlerinden biri olan 'Enhancer of zeste homolog 2' (EZH2), birçok kanserde yüksek oranda ifade edilir"28,29. Ayrıca, EZH2 genindeki mutasyonlar Weaver sendromu ve Ataksi telenjiektazi ile bağlantılıdır³0,31. Çalışmalar ayrıca, pediatrik glioblastomaların üçte birinde replikasyondan bağımsız histon $\mathrm{H}_{3}$ varyantı $\mathrm{H}_{3} .3$ ( $\left.\mathrm{H}_{3} \mathrm{~F}_{3} \mathrm{~A}\right)$ ve kanonik histon $\mathrm{H}_{3} .1$ 'i (HIST1H3B) kodlayan genlerde tekrarlayan somatik mutasyonları göstermiştir ${ }^{2,33}$. SNF5, BRG1 ve MTA1 gibi kromatin yeniden düzenleme ailesinden bazı üyelerin, malignitelerde mutasyona uğradığı bilinmektedir ${ }^{34-36}$. Benzer şekilde, bir histon demetilaz olan UTX, histolojik olarak 12 ayrı kanserde mutasyona uğramaktadır 37 .

Kanser epigenomu konusunda artan bilgi, “epi-miRNA'lar” adı verilen miRNA'ların, DNMT'lar, HDAC'lar veya polipcomb baskılayıcı kompleksler gibi epigenetik düzenleyicileri hedefleyen bir miRNA alt sınıfının varlığını göstermektedir38. EpimiRNA'ların varlığını destekleyen ilk kanıt, akciğer kanserinde miR-29b'nin doğrudan DNMT3A ve DNMT3B'yi hedeflediğinin gösterilmesi olmuştur39.

\section{Terapötik Hedef Olarak Epigenetik}

DNA metilasyonu ve histon modifikasyonlarının geri döndürülebilir olması nedeniyle, hastalıklarda gen ekspresyonunun yeniden düzenlenmesi amacıyla tasarlanmış molekül veya ilaçlar, ilgi çekici terapötik hedefler karşımıza çıkmaktadır. DNMT'ları bloke etmek için tasarlanan ilaçların kanser tedavisinde, özellikle de hematolojik malignitelere karşı yararlı olduğu kanıtlanmıştır40. Bugüne kadar, azasitidin (5azasitidin) ve desitabin (5-aza-2'-deoksisitidin) gibi iki DNMT inhibitörü miyelodisplastik sendromun tedavisi için onaylanmıştır ${ }^{41,42}$. Buna ek olarak, birçok başka DNMT inhibe edici ilaç (örneğin, Zebularin, Prokain, Hidralazin ve Genistein) çalışmalarda denenmektedir43. Ancak, DNMT inhibitörleri sıklıkla, ortak etki mekanizmaları nedeniyle hedeflenen genler dışındaki bölgeleri de etkilemektedir. 
Bununla birlikte, HDAC inhibitörü (trichostatin A, Valproik Asid, SAHA) ve HMT inhibitörleri (Bix-01294) ilaç keşfinde yeni bir düzeyi temsil etmekte ve bu alandaki potansiyeli göstermektedir ${ }^{44}$.

\section{Çevre ve Beslenmenin Epigenetik Üzerine Etkisi}

Yaşam tarzı, enfeksiyonlar, çevresel maruz kalma, mikrobiyom vb. gibi bazı dış faktörler sadece genetik/epigenetik düzenlemeye müdahale etmekle kalmaz, aynı zamanda gen ekspresyon profilini etkileyerek hastalık riskini etkiler (Şekil 3).

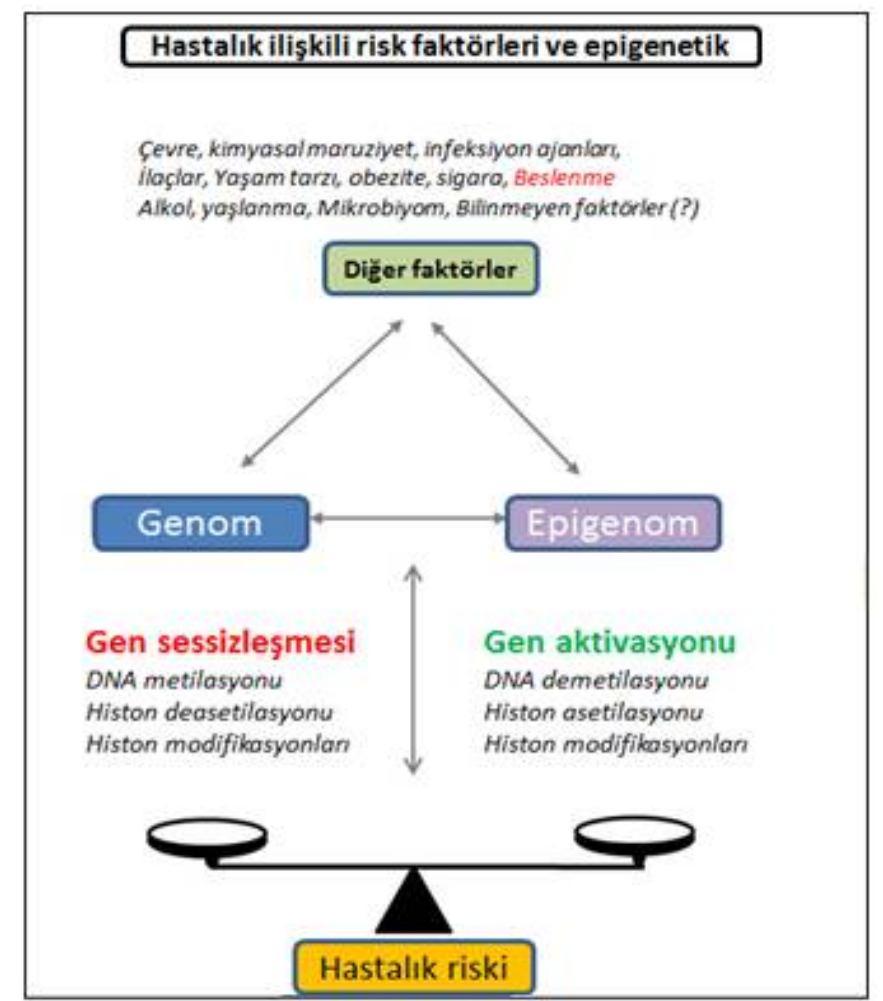

\section{Şekil 3. Hastalık risk faktörleri ve epigenetik etkileşimi}

Genetik ve epigenetik ile çevresel faktörler arasındaki olası etkileşimler birlikte hastalık riskinin oluşmasına yol açar. Gen susturma veya aktifleşmesi arasında bulunan dengenin bozulması hastalığın ortaya çıkması ile sonuçlanabilir. Beslenme, hastalık riskini etkileyen en önemli faktörlerden biridir.

Diyetle alınan folik asit miktarı, DNA, RNA, protein metilasyonu, DNA sentezi ve onarımı için gereken birçok kritik hücre yolağını (örneğin metil grubunun 
üretimi/salımı) etkiler. Son zamanlarda yapılan çok sayıda klinik çalışma, önemli bir metil grubu vericisi olan S-adenozil metiyoninin (SAM) Alzheimer hastalığı, depresyon ve osteoartrit tedavisinde önemli olduğunu göstermiştir45,46. Diğer çalışmalar ayrıca hamilelik surasında folat takviyesinin IGF2 geninin DNA metilasyon seviyelerini değiştirebileceğini ortaya koymaktadır47. Ayrıca, folat gerektiren homosistein gibi diğer ara ürünler de kardiyovasküler hastalıklar, bazı doğum kusurları ve Parkinson hastalığında erken risk belirteci olarak önerilmiştir ${ }^{48,49}$. Bunun dışında, kanser hücrelerinde metiyonin döngüsünü bloke etme stratejileri, olası antikanser tedavileri olarak araştırılmaktadır50. Çalışmalar, diyet dışında tütün dumanına maruz kalma, hava kirliliği ve kadmiyum, kurşun, civa gibi kimyasal ajanların DNA metilasyonu üzerinde önemli etkileri olduğunu göstermiştir ${ }^{1}$. Spesifik olarak, arsenik maruziyetinin global DNA değişiklikleri, histon asetilasyonu, histon fosforilasyonu, miRNA ifade seviyeleri değişikliği ve karsinojenez ile bağlantılı olduğu bidirilmiştir52 ${ }^{2}$ Çeşitli genom bağlantı çalışmaları (GWAS), tek nükleotid polimorfizmi (SNP) veya çevre/ yaşam tarzı faktörlerinin güçlü etkisine sahip hastalıklar için risk allelleri tanımlamak için kullanılır. Bu bağlamda, epigenom çapında ilişkilendirme çalışmaları (EWAS), yaygın hastalıkların altında yatan varyantları ortaya çıkarmak için sistematik bir yaklaşım sağlamak için de kullanılırlar53.

\section{Epigenetik Biyobelirteçlerin Diagnostik Önemi}

İnsan vücudunun en ulaşılabilir dokularından biri olan kan, hastalık riski ile ilgili genetik-epigenetik modellerin araştırılmasında sıklıkla kullanılır. DNA'nın RNA veya protein gibi diğer biyolojik materyallerden daha stabil olduğunu düşünen araştırmacılar, idrar, bronş lavaj sıvısı, anne sütü, balgam, plazma, serum ve periferik kan gibi vücut sıvılarında DNA metilasyonu ile ilgili değişiklikleri saptamak için çaba göstermektedirler. Apoptoz, nekroz, otofaji, nekroptoz ve diğer fizyolojik süreçler yoluyla sağlıklı ve tümör hücrelerinden kan dolaşımına salınan serbest DNA [Dolaşan serbest DNA (cfDNA), dolaşan tümör DNA'sı (ctDNA), mitokondriyal DNA (mtDNA)], özellikle dikkat çekmektedir. Son zamanlardaki araştırmalar, dolaşımdaki bu tür materyalin (genellikle "sıvı biyopsi” olarak adlandırılır) kantitatif analizinin, tümör ilerlemesini değerlendirmek ve çeşitli kanser türlerinde tedaviye yanıtı tahmin etmek için kullanılabileceğini bildirmektedir54. Dahası, yapılan bir çalışmada kanserli bireylerde ctDNA'nın bir kısmının, mutasyonlara ek olarak tümör hücreleri ile aynı 
metilasyon profilini içerdiği bildirilmiştir55. Nükleer DNA'ya benzer şekilde plazma ve serumdan elde edilen alınan mitokondriyal DNA (mtDNA) içeriği de Ewing sarkoma, travma ve mikrobiyal enfeksiyonlar gibi hastalıklarla anlamlı şekilde ilişkilendirilmiştirr6-58. Son zamanlarda, kanserli hastalarda plazma ve serumda tümöre özgü mitokondriyal DNA mutasyonlarının varlığı araştırılmıştır59. Meme kanserinde yapılan bir çalışmada, plazma ve serumda cfDNA seviyelerinin yükseldiği, buna karşın mtDNA seviyelerinin de azaldığ 1 gösterilmiştir6o . cfmtDNA seviyelerinin de Parkinson hastalığının beyin omurilik sıvısında (BOS) değiştiği gösterilmiştir.

Hücre içermeyen nükleer materyalin yanı sıra, vücut sıvılardan kolayca izole edilebilen eksozomlar, kanser, nörodejeneratif hastalıklar, metabolik hastalıklar, bulaşıcı ve diğer hastalıklarla ilişkilendirilmiştir ${ }^{61}$. Bir başka serbest dolaşım materyali olan dolaşımdaki 'nükleozom' seviyeleri kanserlerde (akciğer, meme, kolorektal ve prostat kanserleri dahil olmak üzere), akut bakteriyel enfeksiyon, sepsis, sistemik lupus eritematozus, serebral felç ve travmada artış gösterir. İlerlemiş kanserli hastalarda serum nükleozom düzeylerinin sağlıklı kontrollerden anlamlı derecede yüksek olduğu gösterilmiştir62 Tümörlerde kemoterapi yanıtını göstermede nükleozom miktarının ümit verici bir belirteç olabileceği gösterilmiştir ${ }^{63}$.

\section{Sonuç ve Öneriler}

Epigenetik konusundaki bilginin artması, kliniğe yansıması ile sonuçlanmıştır. Epigenetik, sadece hastalık sürecinde gerçekleşen gen düzenlenmesindeki değişimlere yeni bakış açıları sunmakla kalmamakta, aynı zamanda epigenomik bazlı hedef tedavilere de temel oluşturmaktadır. Bununla birlikte, epigenetik terapötik ajanların seçici olmadıkları ve yan etkilerinin açıkça bilinmediği unutulmamalıdır. Bu nedenle, hastalığı erken dönemde saptamak için yeni likit biyopsi-bazlı biyobelirteçlere gereksinim vardır. Klinik olarak yararlılığı saptanmış epigenetik belirteçler, hastalar arasındaki bireysel farklılıkları ortaya koymakta klinik fayda sağlayabilecektir.

\section{KAYNAKLAR}

1. Waddington CH. The epigenotype.1942. Int J Epidemiol. 2012;41(1):10-3. 
2. Kernohan KD, Cigana Schenkel L, Huang L, et al. Identification of a methylation profile for DNMT1-associated autosomal dominant cerebellar ataxia, deafness, and narcolepsy. Clin Epigenetics. 2016;5(8):91.

3. Hansen RS, Wijmenga C, Luo P, et al. The DNMT3B DNA methyltransferase gene is mutated in the ICF immunodeficiency syndrome. Proc Natl Acad Sci USA. 1999;96(25):14412-7.

4. Ley TJ, Ding L, Walter MJ, et al. DNMT3A mutations in acute myeloid leukemia. N. Engl. J. Med. 2010;363:2424-2433.

5. Yamashita Y, Yuan J, Suetake I, et al. Array-based genomic resequencing of human leukemia. Oncogene. 2010;29:3723-3731.

6. El-Maarri O, Kareta MS, Mikeska T, et al. A systematic search for DNA methyltransferase polymorphisms reveals a rare $\mathrm{DNMT}_{3} \mathrm{~L}$ variant associated with subtelomeric hypomethylation. Hum Mol Genet. 2009;18(10):1755-68.

7. Kosmider O, Gelsi-Boyer V, Cheok M, et al. TET2 mutation is an independent favorable prognostic factor in myelodysplastic syndromes (MDSs). Blood. 2009;114:3285-291.

8. Grossmann V, Kohlmann A, Eder C, et al. Molecular profiling of chronic myelomonocytic leukemia reveals diverse mutations in $>80 \%$ of patients with TET2 and EZH2 being of high prognostic relevance. Leukemia. 2011;25:877-9.

9. Weissmann S, Alpermann T, Grossmann V, et al. Landscape of TET2 mutations in acute myeloid leukemia. Leukemia. 2012;26:934-42.

10. Amir RE, Van den Veyver IB, Wan M, et al. Rettsyndrome is caused by mutations in X-linked MECP2, encoding methyl-CpG-binding protein 2. Nat Genet. 1999;23(2):185-8.

11. Rainier S, Johnson LA, Dobry CJ, et al. Relaxation of imprinted genes in human cancer. Nature. 1993;362:747-749.

12. Ogawa O, Eccles MR, Szeto J, et al. Relaxation of insulin-like growth factor II gene imprinting implicated in Wilms' tumour. Nature. 1993;362:749-751. 
13. Sharp AJ, Stathaki E, Migliavacca E, et al. DNA methylation profiles of human active and inactive X chromosomes. Genome Research. 2011;21:1592-1600.

14. Baylin SB, Jones PA. Epigenetic determinants of cancer. Cold Spring Harb. Perspect. Biol. 2016;8(9):a019505.

15. Costello JF, Frühwald MC, Smiraglia DJ, et al. Aberrant CpG-island methylation has non-random and tumour-type-specific patterns. Nat. Genet. 2000;24:132138.

16. Malta TM, de Souza CF, Sabedot TS, et al. Glioma CpG island methylator phenotype (G-CIMP): Biological and clinical implications. Neuro Oncol. 2017;20:608-620.

17. Weisenberger DJ, Siegmund KD, Campan M, et al. CpG island methylator phenotype underlies sporadic microsatellite instability and is tightly associated with BRAF mutation in colorectal cancer. Nat. Genet. 2006;38:787-793.

18. Nüsgen N, Goering W, Dauksa A, et al. Inter-locus as well as intra-locus heterogeneity in LINE-1 promoter methylation in common human cancers suggests selective demethylation pressure at specific CpGs. Clin Epigenetics. 2015;1:7-17.

19. Mastroeni D, Grover A, Delvaux E, et al. Epigenetic changes in Alzheimer's disease: decrements in DNA methylation. Neurobiol Aging. 2010;31(12):2025-37.

20. Kaut O, Schmitt I, Wüllner U. Genome-scale methylation analysis of Parkinson's disease patients' brains reveals DNA hypomethylation and increased mRNA expression of cytochrome P450 2E1. Neurogenetics. 2012;13(1):87-91.

21. Kaut O, Sharma A, Schmitt I, Hurlemann R, Wüllner U. DNA methylation of DLG4 and GJA-1 of human hippocampus and prefrontal cortex in major depression is unchanged in comparison to healthy individuals. $J$ Clin Neurosci. 2017;43:261-263.

22. Johnson AA, Akman K, Calimport SR, et al. The role of DNA methylation in aging, rejuvenation, and age-related disease. Rejuvenation Res. 2012;15:483494. 
23. Horvath S, Raj K. DNA methylation-based biomarkers and the epigenetic clock theory of ageing. Nat. Rev. Genet. 2018;19:371-384.

24. Muller-Tidow C, Klein HU, Hascher A, et al. Profiling of histone $\mathrm{H}_{3}$ lysine 9 trimethylation levels predicts transcription factor activity and survival in acute myeloid leukemia. Blood. 2010;116:3564-3571.

25. Xia R, Zhou R, Tian Z, et al. High expression of $\mathrm{H}_{3} \mathrm{~K} 9 \mathrm{me} 3$ is a strong predictor of poor survival in patients with salivary adenoid cystic carcinoma. Arch Pathol Lab Med. 2013;137:1761-1769.

26. Ellinger J, Bachmann A, Goke F, et al. Alterations of global histone $\mathrm{H}_{3} \mathrm{~K} 9$ and H3K27 methylation levels in bladder cancer. Urol Int. 2014;93:113-118.

27. Van Den Broeck A, Brambilla E, Moro-Sibilot D, et al. Loss of histone H4K2O trimethylation occurs in preneoplasia and influences prognosis of non-small cell lung cancer. Clin Cancer Res. 2008;14:7237-7245.

28. Pasini D, Emerging DCL. Roles for Polycomb proteins in cancer. Curr Opin Genet Dev. 2016;36:50-58.

29. Yamagishi M, Uchimaru K. Targeting EZH2 in cancer therapy. Curr Opin Oncol. 2017;29(5):375-381.

30. Gibson WT, Hood RL, Zhan SH, et al. Mutations in EZH2 cause Weaver syndrome. Am J Hum Genet. 2012;90(1):110-8.

31. Li J, Hart RP, Mallimo EM, et al. EZH2-mediated $\mathrm{H}_{3} \mathrm{~K} 27$ trimethylation mediates neurodegeneration in ataxia-telangiectasia. Nat Neurosci. 2013;16(12):1745-53.

32. Schwartzentruber J, Korshunov A, Liu XY, et al. Driver mutations in histone H3.3 and chromatin remodelling genes in paediatric glioblastoma. Nature. 2012;482(7384):226-231.

33. Wu G, Broniscer A, McEachron TA, et al. St. Jude Children's Research Hospital Washington University Pediatric Cancer Genome Project. Somatic histone $\mathrm{H}_{3}$ alterations in pediatric diffuse intrinsic pontine gliomas and non-brainstem glioblastomas. Nat Genet. 2012;44(3):251-253. 
34. Versteege I, Se'venet N, Lange $J$, et al. Truncating mutations of hSNF5/INI1 in aggressive paediatric cancer. Nature. 1998;39:203-206.

35. Wilson BG, Roberts CW. SWI/SNF nucleosome remodellers and cancer. Nat. Rev. Cancer. 2011;11:481-492.

36. Li DQ, Pakala SB, Nair SS, et al. Metastasis-associated protein 1/nucleosome remodeling and histone deacetylase complex in cancer. Cancer Res. 2012;72:387-394.

37. Van Haaften G, Dalgliesh GL, Davies H, et al. Somatic mutations of the histone $\mathrm{H}_{3} \mathrm{~K} 27$ demethylase gene UTX in human cancer. Nat Genet. 2009;41:521-523.

38. Malumbres M. miRNAs and cancer: an epigenetics view. Molecular aspects of medicine. 2013;34:863-874.

39. Fabbri M, Garzon R, Cimmino A, et al. MicroRNA-29 family reverts aberrant methylation in lung cancer by targeting DNA methyltransferases $3 \mathrm{~A}$ and $3 \mathrm{~B}$. Proceedings of the National Academy of Sciences of the United States of America. 2007;104:15805-15810.

40. Costa FF. Epigenomics in cancer management. Cancer Manag Res. 2010;2:25565.

41. Voso MT, Scardocci A, Guidi F, et al. Aberrant methylation of DAP-kinase in therapy-related acute myeloid leukemia and myelo-dysplastic syndromes. Blood. 2004;103:698-700.

42. Lübbert M, Suciu S, Baila L, et al. Low-dose decitabine versus best supportive care in elderly patients with intermediate- or high-risk myelodysplastic syndrome (mds) ineligible for intensive chemotherapy: final results of the randomized phase 11 study of the european organisation forresearch and treatment of cancer leukemia group and the german mds study group. J Clin Oncol. 2011;29:1987-96.

43. Bai ZT, Bai B, Zhu J, et al. Epigenetic actions of environmental factors and promising drugs for cancer therapy. Oncol Lett. 2018;15(2):2049-2056. 
44. Tough DF, Lewis HD, Rioja I, et al. Epigenetic pathway targets for the treatment of disease: accelerating progress in the development of pharmacological tools: IUPHAR Review. Br J Pharmacol. 2014;171(22):4981-5010.

45. Papakostas GI. Evidence for S-adenosyl-L-methionine (SAM-e) for the treatment of major depressive disorder. J Clin Psychiatry. 2009;70:18-22.

46. Coppede F. One-carbon metabolism and Alzheimer's disease: focus on epigenetics. Curr Genomics. 2010;11:246-260.

47. Hoyo C, Murtha A, Schildkraut J, et al. Methylation variation at IGF2 differentially methylated regions and maternal folic acid use before and during pregnancy. Epigenetics. 2011;6(7):928-936.

48. Nygård O, Nordrehaug JE, Refsum H, et al. Plasma homocysteine levels and mortality in patients with coronary artery disease. N Engl J Med. 1997;337:230237.

49. Mattson MP, Shea TB. Folate and homocysteine metabolism in neural plasticity and neurodegenerative disorders. Trends Neurosci. 2003;26:137-146.

50. Sanderson SM, Gao X, Dai Z, Locasale JW. Methionine metabolism in health and cancer: a nexus of diet and precision medicine. Nat Rev Cancer. 2019;19:625637.

51. Ruiz-Hernandez A, Kuo CC, Rentero-Garrido P, et al. Environmental chemicals and DNA methylation in adults: a systematic review of the epidemiologic evidence. Clin Epigenetics. 2015;7:55

52. Ren X, McHale CM, Skibola CF, et al. An emerging role for epigenetic dysregulation in arsenic toxicity and carcinogenesis. Environ Health Perspect. 2011;119(1):11-9.

53. Paul DS, Beck S. Advances in epigenome-wide association studies for common diseases. Trends Mol Med. 2014;20(10):541-3.

54. Schwar Marrugo-Ramírez J, Mir M, Samitier J. Blood-based cancer biomarkers in liquid biopsy: a promising non-invasive alternative to tissue biopsy. Int $J \mathrm{Mol}$ Sci. 2018;19(10):2877. 
55. Schwarzenbach H, Hoon DS, Pantel K. Cell-free nucleic acids as biomarkers in cancer patients. Nat Rev Cancer. 2011;11(6):426-37.

56. Yu M, Wan YF, Zou QH. Cell-free circulating mitochondrial DNA in the serum: a potential non-invasive biomarker for Ewing's sarcoma. Arch Med Res. 2012;43:389-394.

57. Zhang Q, Raoof M, Chen Y, et al. Circulating mitochondrial DAMPs cause inflammatory responses to injury. Nature. 2010;464:104-107.

58. Sursal T, Stearns-Kurosawa DJ, Itagaki K, et al. Plasma bacterial and mitochondrial DNA distinguish bacterial sepsis from sterile systemic inflammatory response syndrome and quantify inflammatory tissue injury in nonhuman primates. Shock. 2013;39:55-62.

59. Weerts MJA, Timmermans EC, van de Stolpe A, et al. Tumor-specific mitochondrial DNA variants are rarely detected in cell-free DNA. Neoplasia. 2018;20(7):687-696.

6o. Mambo E, Chatterjee A, Xing M, et al. Tumor-specific changes in mtDNA content in human cancer. Int $J$ Cancer. 2005;116(6):920-4.

61. Lin J, Li J, Huang B, et al. Exosomes: novel biomarkers for clinical diagnosis. Scientific World Journal. 2015;2015:657086.

62. Holdenrieder S, Nagel D, Schalhorn A, et al. Clinical relevance of circulating nucleosomes in cancer. Ann N Y Acad Sci. 2008;1137:180.

63. McAnena P, Brown JA, Kerin MJ, et al. Nucleosome modifications as biomarkers in cancer. Cancers (Basel). 2017;9(1):5. 